Article

\title{
Do Labour Rights Matter for Export? A Qualitative Comparative Analysis of Pineapple Trade to the EU
}

\author{
Annelien Gansemans ${ }^{1, *}$, Deborah Martens ${ }^{2}$, Marijke D’Haese ${ }^{1}$ and Jan Orbie ${ }^{2}$ \\ ${ }^{1}$ Department of Agricultural Economics, Ghent University, 9000 Ghent, Belgium; E-Mails: annelien.gansemans@ugent.be \\ (A.G.), marijke.dhaese@ugent.be (M.D.) \\ ${ }^{2}$ Centre for EU Studies, Department of Political Science, Ghent University, 9000 Ghent, Belgium; \\ E-Mails: deborah.martens@ugent.be (D.M.), jan.orbie@ugent.be (J.O.) \\ * Corresponding author
}

Submitted: 27 June 2017 | Accepted: 9 October 2017 | Published: 14 December 2017

\begin{abstract}
Labour norms are increasingly considered in trade relations, but is the protection of labour standards a necessary condition for export to the EU? A Qualitative Comparative Analysis, based on countries that export pineapples to the EU, shows that labour standards protection matters in combination with distance, zero tariffs and institutional quality in a number of cases. However, for none of the cases was it a sufficient condition on its own for determining exports to the European market. Rather, we show that (1) having a zero tariff is necessary for a relatively large share of export to the EU, and (2) labour standards protection can make a difference when the institutional quality is weak in some African cases, in contrast to Latin American exporters.
\end{abstract}

\section{Keywords}

agricultural trade; globalisation; institutions; labour rights; political economy; QCA

\section{Issue}

This article is part of the issue "Labour Standards in a Global Environment", edited by Gerda Van Roozendaal (University of Groningen, The Netherlands) and Jan Orbie (Ghent University, Belgium).

(C) 2017 by the authors; licensee Cogitatio (Lisbon, Portugal). This article is licensed under a Creative Commons Attribution 4.0 International License (CC BY).

\section{Introduction}

Fruits and vegetables consumed in Europe are sourced from all over the world. The EU is the world's biggest importer of agricultural products, ahead of the US and China (European Commission, 2015a). Increasing global trade and competitive pressure have changed the nature of food production systems in the South, with significant implications for rural populations (Hurst, 2005). Many private voluntary governance mechanisms now regulate the social and environmental conditions in production, with private labels increasingly addressing production process characteristics, including working conditions (O'Rourke, 2003). At the same time, interest groups in Europe put pressure on firms to limit their use of imports from countries with poor labour practices through naming and shaming campaigns targeted at companies which fail to comply with social standards in their supply chain (Fair Trade Advocacy Office [FTAO], 2015a). Policywise, labour norms are increasingly considered in trade agreements, the aim being to make trade conditional upon compliance with international conventions (Van den Putte \& Orbie, 2015).

Despite the growing interest in labour issues among firms, consumers and policy makers, the importance of social conditions, such as the protection of labour rights, as a determinant for trade remains understudied (International Labour Organisation [ILO], 2016; Kucera \& Sarna, 2006). Most publications follow a logic of cost efficiency to explain trade performance, revealing a race to the bottom in labour standards (Hefeker \& Wunner, 2002). A question yet to be clarified, however, is whether 
exporting countries that comply with labour standards are rewarded with a relatively larger export share to the European market, especially in trade of agricultural products. We address this gap in the literature by questioning how levels of labour rights protection, in addition to institutional quality, tariff regimes and exporting countries' distance to the EU, affect the share of unilateral exports to the EU. We argue that countries with better levels of labour rights protection, high institutional quality, preferential tariffs and closer distance export a relatively larger share to the EU. Along the same lines, a producer country far away from the EU, without good institutional quality and/or with low protection of labour rights, is expected to export a less important share of produce to the EU.

A Qualitative Comparative Analysis (QCA) approach was used to determine the necessary and sufficient conditions for a high dependency on the EU market for a country's pineapple exports. This approach differs from the analysis of trade flows in gravity models (Kucera \& Sarna, 2006), because it allows causal complexity to be addressed by testing several paths or combinations that lead to the same outcome (see infra). We focus on fresh pineapples, an important agricultural export product in terms of traded volumes around the world and export value. This case selection is rooted in the labour-intensive nature of production and highly visible labour challenges.

As will be explained in the next section, consumers in the EU market are said to be particularly sensitive to ethical and labour issues, and this is manifested at different levels, such as trade agendas, private labelling and consumer behaviour. In this article we search for evidence that labour protection levels do indeed matter for a country to trade intensively with the EU. The remainder of the article is structured as follows. In the next section, the importance of labour standards in trade is explained and a theoretical justification is provided for the conditions considered in this study. Section Three justifies the QCA methodology and describes the data sources. Section Four discusses the results before concluding the article.

\section{Theoretical Justification for the Included Conditions}

\subsection{Labour Rights as a Determinant of Exports}

Trade between countries may be conditional on prior levels of respect for labour rights in partner countries (Mosley \& Uno, 2007). According to conventional wisdom, businesses are likely to prefer low labour cost producing countries over labour quality because of competitive pressure and profit concerns. This would induce a race to the bottom in labour conditions (Kucera, 2001). However, recent literature has demonstrated how labour rights can affect trade positively. Proponents of a positive labour rights-trade hypothesis assume that countries, or firms, purposely select partners that perform well in terms of labour standards because of reputational concerns or external ethically driven pressures (Greenhill, Mosley, \& Prakash, 2009). Moreover, developed countries could serve as role models for developing countries through market integration, which can result in the harmonisation of institutions and regulatory arrangements (Kucera \& Sarna, 2006; Neumayer \& de Soysa, 2006). At firm level, Toffel, Short and Ouellet (2015) found better labour rights compliance among suppliers serving buyers located in countries where consumers are wealthy and socially conscious. In addition, Distelhorst and Locke (2017) concluded that importers favour doing business with companies that comply with basic labour and environmental standards.

The debate has intensified over the last few years, not least because of the devastating consequences of the collapse of the Rana Plaza building in Bangladesh (Reinecke \& Donaghey, 2015). There are indications that both European consumers and public bodies across the EU have increasingly valued labour rights protection in their consumer decisions and public policies (Mosley, 2017).

The consumer is increasingly being considered as an important actor and driver of labour governance, both through purchasing power and voice power (Donaghey, Reinecke, Niforou, \& Lawson, 2014; Kolben, 2017, in this issue). Stolle and Micheletti (2013, pp. 96-98) point to the European Social Survey (2003), and the Citizenship, Involvement, and Democracy Survey in the US (2006), which demonstrated that about $31 \%$ of all people interviewed reported engaging in "political" consumption behaviour. Purposely buying labelled products (buycotting) and rejecting other products (boycotting) reflects the individual responsibility taken by consumers to foster sustainable development. In the US, $28 \%$ of the respondents reported engaging in such political consumption behaviour, while in European countries the level is higher, exemplified by $60 \%$ of the respondents in Sweden. A recent survey on behalf of DG DEVCO revealed that $50 \%$ of the respondents (out of 27,672 in the $28 \mathrm{EU}$ member states) would be prepared to pay more for groceries (such as fair trade products) from developing countries to support people living in those countries (Eurobarometer, 2016). The retail sales of fair trade products, the world's leading ethical label, also point to a relatively high demand for labelled products in the European market. Global fair trade sales were estimated at EUR 7.3 billion in 2015. The EU is the most important region for fair trade products, accounting for almost $80 \%$ of the world retail sales, with the UK (30\%) and Germany (13\%) being the leading buyers of fairly produced products, while the US accounts for $12 \%$ of sales (Fair Trade International, 2016).

The EU has elaborated a trade and investment policy based on values in its latest trade strategy, "Trade

\footnotetext{
${ }^{1}$ The Fair Trade Advocacy Office proposed actions to the EU to require "transparency in supply chains and a system of due diligence...that requires persons placing products on the EU market to ensure compliance with labour, environmental rights of the country of origin. This could be applied to agricultural products and also to textiles" (FTAO, 2015b, p. 9).
} 
for All". The Communication refers to the expectations of EU consumers ${ }^{1}$ concerning respect for human rights, labour rights and the environment during the production of the goods they use (European Commission, 2015a, p. 20). However, since most production occurs along value chains that criss-cross developed and developing economies alike, the Commission acknowledges the challenging reality of meeting these expectations. These elements are reiterated in the 2017 review of the EU trade strategy (European Commission, 2017, pp. 2, 9-10). First, high standards of labour protection are confirmed as being fundamentals of the "Trade for All" strategy. Second, the ambition to continue to make trade "a positive force around the globe" and to shape globalisation to promote sustainable development with a trade policy based on "EU and universal values" has been affirmed. Third, consumer concerns are taken into account as "the EU continues to pursue new avenues in making trade policy more responsive to citizen's concerns". The European Parliament (2017) has confirmed these demands from EU consumers in its resolution on the impact of international trade and the EU's trade policies on global value chains, recalling that "no consumer wants to continue buying products made by children or exploited men and women".

A number of EU trade instruments incorporate the necessity to respect labour rights. In its Generalised Scheme of Preferences plus (GSP+, see infra), the EU grants beneficial market access to developing countries that ratify and implement, amongst others, the ILO core conventions (Velluti, 2015). In addition, all the new generation EU trade agreements, starting with the EU-Korea agreement in 2011, include a chapter on "Trade and Sustainable Development", in which the Parties pledge to adhere to the ILO core conventions, amongst others (see Van den Putte \& Orbie, 2015). Finally, ad hoc instruments have been developed to address labour rights violations in specific value chains. For example, the Global Sustainability Compact aims to improve labour conditions in the garment industry in Bangladesh (Vogt, 2017, in this issue). In addition to these trade instruments, the role of and collaboration with private actors in labour governance have also received more policy attention and Corporate Social Responsibility initiatives ${ }^{2}$ are increasingly supported, directly and indirectly, by the EU (Knudsen \& Moon, in press).

Following this line of argument on the importance of labour standards in EU trade, the article engages with the positive trade-labour assumption by examining whether exports to the EU are conditional upon the level of protected labour rights in the exporting country. By confirming this assumption, we can broadly conclude that, in line with claims made by policy makers, Europe is actually a more social market. This also implies that exporting producers and governments have an interest in improving social conditions at firm and national level in order to boost their exports to the EU. If the results reject the assumption, we can conclude that the perception of the European market as being very demanding with regard to social standards is not in line with reality, resulting in an overestimation of European consumer and retailer power to raise the bar on social standards.

\subsection{Institutional Quality as a Determinant of Exports}

An enabling institutional environment attracts foreign investment and facilitates trade through more secure property rights, contract enforcement and investor protection (Levchenko, 2007; Rodrik, 1996). Anderson and Marcouiller (2002) showed that better institutional quality leads to larger trade volumes. A similar positive influence of domestic institutions on bilateral trade flows was found by Jansen and Nordås (2004). Absence of good governance, especially a weak regulatory framework, can be an obstacle to trade (Méon \& Sekkat, 2008). For example, the decline in pineapple export share to the EU from Côte d'Ivoire since the mid-1980s was partly explained by political instability, high turnover of private and public institutions, withdrawal of state support for the agricultural sector, and the civil war (Vagneron, Faure, \& Loeillet, 2009). Institutions, as business facilitators, may also indirectly affect trade through the relationship with investment (Pajunen, 2008). European importers particularly value a positive institutional environment in-country, because a good judicial system makes it easier to do business and facilitates contract enforcement (Richards, Gelleny, \& Sacko, 2001).

\subsection{Tariffs as a Determinant of Exports}

Preferential or zero tariff rates in trade agreements can foster exports through facilitated access to the European market. Higher tariff rates for a specific product or country can work as a barrier, increasing export costs. However, the impact of tariffs differs by country and product (Emlinger, Jacquet, \& Chevassus Lozza, 2008).

The EU has developed a number of trade regimes to manage access to its market. The EU provides preferential market access through bilateral agreements and has elaborated specific trade regimes for developing countries. The latter are mainly unilateral trade arrangements including "Everything but Arms", initiatives providing duty-free and quota-free access for the least developed countries, the GSP, which allows vulnerable developing countries to pay fewer or no duties on exports to the EU, and the GSP+, which combines more generous market access with sustainable development, governance and trade conditionality. While the former colonies, mainly referred to as the African, Caribbean and Pacific (ACP) group, long stood at the top of the EU's "pyramid of preferences", their position has been eroded. This has been a gradual evolution in which reciprocal (yet still asym-

\footnotetext{
${ }^{2}$ For example, several member states are actively involved in promoting sustainable supply chains by financially supporting and participating in multistakeholder initiatives such as the Dutch Sustainable Trade Initiative (Initiatief voor Duurzame Handel, IDH) and the UK Ethical Trading Initiative (ETI).
} 
metrical) free trade has trumped the development aspiration of the EU trade agenda (for an overview see Orbie \& Martens, 2016).

In general, the classical policy instruments, such as tariffs, have lost much of their importance due to liberalisation processes and new trade agreements (Hefeker \& Wunner, 2002). Indeed, in 2014, about $71 \%$ of all agricultural imports entered the EU at zero duty, representing a value of EUR 72 billion (European Commission, 2015b). This demonstrates that factors other than tariffs are expected to influence trade with the EU (Emlinger et al., 2008).

\subsection{Distance as a Determinant of Exports}

Countries that are located close to the EU are expected to export more to the EU because of lower transportation costs (De Groot, Linders, Rietveld, \& Subramanian, 2004). Moreover, some of these countries may also benefit from historical relations and development assistance to strengthen their capacity in productive sectors through infrastructure and human capital investment (Babarinde \& Faber, 2007). These historical ties may facilitate more direct, stable export relations between producer firms in the former colonies and buyers in the former European colonisers (Emlinger et al., 2008).

\section{Methodology}

\subsection{Case Selection}

The fresh pineapple sector was selected due to its large direct export flow with few processing steps in the value chain, the labour-intensive production process, and the increased consumption in Europe. Pineapples are produced in various countries, mainly on large plantations dominated by three multinationals: Del Monte, Dole and Chiquita (Centre for the Promotion of Imports from Developing Countries, 2015). The focal area for pineapple production is Costa Rica, which is the largest fresh pineapple exporter to the EU, accounting for $85 \%$ of European supplies in 2013 (COMEXT, 2015). In fact, ACP producers have lost a large market share while imports from Costa Rica have multiplied over the past decade (Vagneron et al., 2009), as Costa Rica started to cultivate the MD-2 variety which is in high demand on the market.

The dataset used in this study consists of 44 pineapple producing and exporting countries (i.e. actors or units of analysis). The fresh pineapple export volumes to the European market were derived from the United Nations COMTRADE (2015) and Eurostat COMEXT (2015) databases (HS code 080430). Countries with less than 500 metric tonnes of total export volume were excluded from the analysis because of their negligible economic value, resulting in 26 valid cases-too few for an econometric analysis and too many for an in-depth qualitative analysis. Hence, a QCA modelling approach was chosen.

\subsection{Data Sources}

\subsubsection{The Outcome: EXP}

The outcome is defined as the share of pineapple exports to the EU compared to other destinations. It represents the relative importance or dependency on the EU market as a destination for pineapples in each exporting country considered in the model, which is quantified by the volume of exported pineapples to the EU from a specific country divided by the total pineapple exports in that country for the year 2012. Our model does not consider bilateral trade between individual countries as could be done in gravity models; instead, it analyses unilateral flows from the trade partner country to the European Union member states, which comprise one group for this purpose, the EU market. Some countries, notably in Africa, export exclusively or a large share of their pineapple to the EU. In contrast, Latin American countries export only half of their total pineapple exports or less to the EU as for them the US is an important market. Asian countries mainly trade processed canned pineapple, which we excluded from our analysis.

\subsubsection{The Conditions: LAB, INST, TAR, DIST}

LAB. There is no commonly approved index to measure and capture the different labour rights dimensions (Anker, Chernyshev, Egger, Mehran, \& Ritter, 2003; Compa, 2003; Cuyvers \& Van Den Bulcke, 2007; Teitelbaum, 2010). Measures at firm level include wage, working time and occupational health and safety, which are referred to as outcome rights (Barrientos \& Smith, 2007). At country level, the four core ILO conventions are generally mentioned, namely freedom of association and the right to collective bargaining (referred to in the remainder of this article as Freedom of Association and Collective Bargaining [FACB] rights), no forced labour, no child labour, and no discrimination at the workplace. Out of these four dimensions we consider the collective bargaining rights as the lever to improved labour conditions in the agricultural sector where wages are low and workers tend to be worse off compared to those employed in other occupational sectors (Mosley, 2008). These 'enabling' FACB rights are conducive to access to outcome rights such as wage and working time (Barrientos \& Smith, 2007), yet the right to form an independent workers' organisation is still suppressed in many countries, especially in agricultural sectors where unionisation is low (Hurst, 2005). Neumayer and de Soysa (2006) argued that globalisation is more likely to promote FACB rights than the outcome rights.

The QCA model presented in this article uses the most recent labour rights (LR) indicator (Kucera \& Sari, 2016). The LR indicator distinguishes between two elements of workers' rights: the legal ratification of the ILO conventions (de jure) and their practical implementation (de facto). The LR indicator consists of 108 distinct eval- 
uation criteria for de jure and de facto violations which are grouped in five categories: (1) fundamental civil liberties, (2) right of workers to establish and join organisations, (3) other union activities, (4) right to collective bargaining, and (5) right to strike. Factual information is obtained from the coding of nine textual sources ${ }^{3}$. The final indicator scores countries from 0 to 10 (respectively the best and the worst possible score).

INST. The World Bank Governance Indicators are widely used to measure institutional quality (Kaufmann, Kraay, \& Mastruzzi, 2010). The indicators are based on the opinion of a large number of enterprise, citizen and expert survey respondents, including 32 individual data sources. It consists of six dimensions measured on a scale of -2.5 to 2.5 (with 2.5 as the best score): voice and accountability, political stability, government effectiveness, regulatory quality, rule of law, and control of corruption. The dimension rule of law was selected in this study because it captures the perceptions of confidence in abiding by the rules, in particular the quality of contract enforcement, property rights, police and courts, which is relevant in trade relations (Kaufmann et al., 2010).

TAR. We compared the trade regime and the productspecific tariff line for pineapple applied to each country in 2012, derived from the TARIC database (European Commission, 2016). Bolivia, Costa Rica, Ecuador, Guatemala, Honduras and Paraguay fell under the GSP+ scheme. Benin, Thailand, Togo and Uganda had an EBA agreement. Other countries had a GSP agreement except for the USA for which normal tariffs apply. The GSP trade regime did not guarantee zero tariffs for pineapple in the case of China, Brazil, India, Malaysia, Philippines and Thailand. Therefore we opted to account for the variation in tariff lines for pineapple. A dummy variable was constructed for having a zero tariff rate.

DIST. This article uses the distance measures developed by the Centre d'Etudes Prospectives et $d^{\prime}$ Informations Internationales (CEPII) to determine the distance between Brussels as Europe's institutional centre and each capital city in the world (Mayer \& Zignago, 2011).

\subsection{Qualitative Comparative Analysis}

QCA differs in several respects from traditional statistical methods and is increasingly being applied in comparative political research at country level (Giumelli \& Van Roozendaal, 2016; Pajunen, 2008).

First, the objective of the study is not to estimate if a variable or an interaction term has a positive or negative significant effect on a dependent variable as in the gravity model of Kucera and Sarna (2006), who found a limited positive effect of FACB on total export trade. Instead, we seek to identify the different combinations of conditions that lead to the outcome, the relative importance of the EU as export market, because it is theoretically more likely that various paths for specific cases bring about this outcome.

Second, QCA and regression analysis have different explanatory approaches, each of which lends itself to different research questions and hypotheses (Vis, 2012). QCA follows a causes-of-effects approach, because the goal is to explain the different causal patterns in the cases under study that produce specific outcomes (effects), such as dependency on the EU market for pineapple exports in this study. Quantitative approaches adopt an effects-of-causes approach, with the central objective to estimate the average effect of one (or more) variables in a sufficiently large sample. Hence, a QCA is well-suited to address the question of why some countries are exporting relatively more to the $\mathrm{EU}$ and others not, because the outcome is probably shaped by combinations of factors and not by one causal model with individual factors in isolation.

Moreover, QCA is especially appropriate for small to medium $n$-samples where regressions are problematic (Marx, Rihoux, \& Ragin, 2014). We do not focus on worldwide bilateral trade flows (exports and imports between all countries in the world) as in gravity models. Instead we want to compare cases of countries having a high or low dependency on exports to the EU, in particular for pineapple as a labour-intensive agricultural product.

The essence of QCA is to understand the combination of conditions that is necessary and/or sufficient for a certain outcome. The QCA method focuses on relations of implication (absence or presence of conditions), while in regression models the causation is assumed to be linear, testing hypotheses about relations of covariation or correlation between the independent and dependent variables (Katz, Vom Hau, \& Mahoney, 2005; Thiem, Baumgartner, \& Bol, 2016).

A first advantage is that QCA allows for equifinality, or in other words, different causal paths can explain the same effect. This notion of equifinality is omitted in most mainstream statistical methods, which serve to assess the average effect of one individual factor (Grofman \& Schneider, 2009). It is true that regression analysis can also account for a combination of conditions through interaction terms, but the interpretation is less straightforward than in QCA and the number of interaction terms that can be included is limited (Vis, 2012). QCA cannot simply be substituted by an interaction-based regression model, because it is hard to deal with many high order interaction terms without violating statistical assumptions (Marx et al., 2014). Even with interactions, regression models are insensitive to the differences between necessity and sufficiency (Grofman \& Schneider, 2009, p. 669; Vis, 2012, p. 173).

\footnotetext{
${ }^{3}$ Country Reports on Human Rights Practices (US Department of State), Annual Survey of Violations of Trade Union Rights (International Trade Union Confederation-ITUC), ILO's Reports of the Committee on Freedom of Association, Reports of the Committee of Experts on the Application of Conventions and Recommendations, Reports of the Conference Committee on the Application of Standards, Country Baselines Under the ILO Declaration Annual Review, Representations under Article 24 of the ILO Constitution, Complaints under Article 26 of the ILO Constitution, and the relevant national legislation for non-ratifying countries.
} 
A second advantage is that QCA explains why specific groups of cases fit with a combination of factors. Moreover, a coefficient might appear not statistically significant in regression results or an extreme value might be seen as an outlier, while it can still be informative and crucial as a condition explaining the occurrence of a few cases in a QCA solution (Grofman \& Schneider, 2009; Katz et al., 2005). QCA thus has the advantage that it has less severe data requirements than regressions (Vis, 2012).

The following steps were adopted in the QCA approach. The number of cases complies with the minimal number of cases needed for a QCA. This is calculated as $2^{k}$ with $k$ the number of conditions. As we consider four conditions (see above), we need a minimum of 16 cases to have a reliable solution. The 26 countries thus represent an intermediate $\mathrm{N}$-situation, for which QCA is particularly adequate.

QCA is a set-theoretic approach to test causal complexity based on the notion of sets, set membership scores and set relations to find the necessary and sufficient conditions. A condition is considered necessary if whenever the outcome is observed, the condition was present. A condition is sufficient if whenever the condition was present, the outcome also occurred.

In a QCA model, the outcome and conditions are formulated in terms of set membership, with a value assigned to each individual case, indicating the extent to which it belongs to the set. This data needs to be calibrated using empirical information on the cases in order to assign set membership scores that vary between 0 and 1 . Membership scores are calculated using both crisp set ( $0=$ out or $1=$ in the set) as fuzzy set approaches. Fuzzy set models allow for partial membership in the set. When calibrating the fuzzy set data, a threshold or point of indifference (0.5) needs to be defined; this allows a qualitative distinction to be made in the case of membership. Fuzzy sets also require the selection of anchor points between full set membership (1) and full non-membership (0). From the three commonly used calibration methods (theory-guided qualitative, direct and indirect), we apply the qualitative approach that identifies meaningful anchors based on conceptual and case knowledge.

Through such a qualitative calibration method, the fuzzy set anchor points determined the threshold values for each of the four levels within a set: 0 (no membership), 0.33 (partial non-membership, more out than in the set), 0.67 (partial membership, more in than out), and 1 (full membership) (Table 1). For the outcome vari- able, the cases with an export share of less than 0.05 were recalibrated as "no dependency" on the EU market for pineapple export (0), values between 0.05 and 0.3 were assigned to the "low dependency" subset (0.33), values between 0.3 and 0.7 belonged to the "intermediate dependency" subset (0.67) and values above 0.7 covered the "highly dependent" cases (1). The point of indifference for the fuzzy set "many labour rights violations" is considered in the middle of the scale as 0.5 , meaning that cases passing this threshold are more in the set (1) than out (0). For the crisp set enabling institution, the cases with a value below -0.50 on the original scale of -2.5 to 2.5 were recalibrated to zero (no enabling institutions) and above -0.5 to 1 (enabling institutions). The dummy of tariff rates is already binary and did not have to be recalibrated. The distance to the EU over 10,000 km was calibrated as "very far" (1), between 6,000 and $10,000 \mathrm{~km}$ as "far" (0.67), between 4,000 and $6,000 \mathrm{~km}$ as "intermediate" (0.33), and less than 4,000 km as "close" (0).

Table A1 of the annex compares the calibrated data used in the analysis with raw data values. The fit of a QCA is measured by its consistency and coverage. "Consistency" measures the degree to which a relation of sufficiency between a causal condition (or combination of conditions) and an outcome is met within a given data set (Ragin, 2006). Consistency values range from 0 (no consistency) to 1 (perfect consistency). Once it has been established that a condition or combination of conditions is consistent with sufficiency, coverage provides a measure of empirical relevance, or the extent to which this combination of conditions is covered by empirical cases. There are three measures for coverage of different parts of the solution in the case of equifinality (i.e. more than one different solution path lead to the same outcome) (Ragin, 2006). The solution coverage refers to how much is covered by the solution term. The raw coverage (cov.r) indicates which share of the outcome is explained by each alternative path. The unique coverage (cov.u) refers to the share of the outcome that is exclusively explained by a specific alternative path.

The QCA package of the software programme $R$ was used to analyse the necessary and sufficient conditions.

\section{Results}

This section presents the results of the QCA model that examines which (combined) factors are necessary and

Table 1. Calibration of anchor points for the conditions and outcome.

\begin{tabular}{lll}
\hline Set name & Type & Anchor points (range of calibrated values) \\
\hline High importance EU (EXP) & Fuzzy & $(0)<\mathbf{0 . 0 5}(0.33)<\mathbf{0 . 3}(0.67)<\mathbf{0 . 7}(1)$ \\
Many labour rights violations (LAB) & Fuzzy & 0.5 \\
Enabling institutions (INST) & Crisp & $(0)<-\mathbf{0 . 5 0}<(1)$ \\
Zero tariff (TAR) & Crisp & $1($ zero tariff), 0 (no zero tariff) \\
Far from the EU (DIST) & Fuzzy & $(0)<\mathbf{4 , 0 0 0}(0.33)<\mathbf{6 , 0 0 0}(0.67)<\mathbf{1 0 , 0 0 0}(1)$ \\
\hline
\end{tabular}


sufficient conditions for a high importance of the EU market for pineapple exports. The first step in a QCA after calibration is to check for necessary conditions. This is done separately from the analysis of sufficient conditions, which is the second step.

\subsection{Analysis of Necessary Conditions}

The necessity solution is determined by a threshold of consistency equal to 0.9 and the coverage should not be lower than 0.5 (Ragin, 2006).

Table 2 shows one necessary condition for the occurrence of the outcome, namely zero tariffs, with a consistency score of 0.937 and a coverage value of 0.527 , slightly above the corresponding threshold levels. Whenever the outcome (relatively large share of pineapples exported to the EU) occurs, the condition zero tariff is present. This suggests that having a zero tariff is necessary for a high relative importance of the EU market for pineapple exports.
The analysis was repeated for the non-occurrence $(\sim)$ of the outcome and conditions, which is a qualitatively different event than its occurrence. None of the necessary conditions scored above the threshold level of 0.9.

\subsection{Analysis of Sufficient Conditions}

The truth table (Table 3) summarises all possible combinations of the four conditions, here 16 rows, for the outcome that the EU is an important export market. Each row identifies the possible combinations of conditions and the cases that belong to that combination. Some of the rows in the truth table are empty because there were no empirical cases for these combinations of conditions.

Next, the truth table is minimised towards a conservative solution. For this purpose, an inclusion threshold score for sufficiency of 0.75 or higher is considered (Schneider \& Wagemann, 2012), which means that 75\% of the cases' membership scores in a combination of conditions must be consistent. Cases with a consistency

Table 2. Analysis of necessity for the (non-)occurrence of the outcome with consistency, coverage and relevance of necessity values.

\begin{tabular}{lllllrr}
\hline \multirow{2}{*}{ Conditions } & \multicolumn{2}{c}{ Consistency } & \multicolumn{2}{c}{ Coverage } & \multicolumn{2}{c}{ RoN } \\
\cline { 2 - 6 } & EXP & $\sim$ EXP & EXP & $\sim$ EXP & EXP & $\sim$ EXP \\
\hline LAB & 0.480 & 0.583 & 0.441 & 0.769 & 0.689 & 0.842 \\
$\sim$ LAB & 0.748 & 0.576 & 0.556 & 0.614 & 0.646 & 0.677 \\
INST & 0.469 & 0.522 & 0.385 & 0.615 & 0.619 & 0.722 \\
$\sim$ INST & 0.531 & 0.478 & 0.436 & 0.564 & 0.639 & 0.696 \\
TAR & 0.937 & 0.587 & 0.527 & 0.473 & 0.438 & 0.412 \\
$\sim$ TAR & 0.063 & 0.413 & 0.096 & 0.904 & 0.750 & 0.966 \\
DIST & 0.621 & 0.850 & 0.354 & 0.695 & 0.375 & 0.559 \\
$\sim$ DIST & 0.850 & 0.209 & 0.695 & 0.442 & 0.559 & 0.823 \\
\hline Notes: & & &
\end{tabular}

Notes: TAR: zero tariff; LAB: many labour violations; DIST: far from EU; INST: enabling institutions; EXP: high importance EU.

Table 3. Truth table for the importance of EU for pineapple exports with conditions TAR, LAB, DIST and INST.

\begin{tabular}{llllllll}
\hline TAR & LAB & DIST & INST & EXP & $\mathbf{n}$ & incl & Cases \\
\hline 1 & 1 & 1 & 1 & 1 & 2 & 0.857 & Panama, Colombia \\
1 & 0 & 0 & 0 & 1 & 3 & 0.856 & Benin, Côte d'Ivoire, Togo \\
1 & 1 & 0 & 0 & 0 & 1 & 0.749 & Cameroon \\
1 & 0 & 0 & 1 & 0 & 1 & 0.732 & Ghana \\
1 & 0 & 1 & 1 & 0 & 4 & 0.709 & Costa Rica, Mauritius, South Africa, Uganda \\
1 & 1 & 1 & 0 & 0 & 1 & 0.449 & Guatemala \\
1 & 0 & 1 & 0 & 0 & 7 & 0.440 & Bolivia, Dom. Rep., Ecuador, Honduras, Mexico, Paraguay, Tanzania \\
0 & 0 & 1 & 1 & 0 & 1 & 0.187 & Brazil \\
0 & 1 & 1 & 1 & 0 & 4 & 0.173 & China, India, Malaysia, Thailand \\
0 & 0 & 0 & 1 & 0 & 1 & 0.080 & USA \\
0 & 1 & 1 & 0 & 0 & 1 & 0.000 & Philippines \\
0 & 0 & 0 & 0 & $?$ & 0 & - & \\
0 & 0 & 1 & 0 & $?$ & 0 & - & \\
0 & 1 & 0 & 0 & $?$ & 0 & - & \\
0 & 1 & 0 & 1 & $?$ & 0 & - & \\
1 & 1 & 0 & 1 & $?$ & 0 & - & \\
\hline
\end{tabular}

Notes: TAR: zero tariff; LAB: many labour violations; DIST: far from EU; INST: enabling institutions; EXP: high importance EU; $n$ : number of cases; incl: inclusion of sufficiency score. 
value higher than 0.75 were assigned a 1 in the outcome for the minimisation process.

Table 4 suggests that the outcome is reached through two solution paths, which is given in QCA notation ${ }^{4}$ as: TAR $^{*} \sim$ INST $^{*} \sim \mathrm{DIST}^{*} \sim \mathrm{LAB}+\mathrm{TAR}^{*} \mathrm{INST}^{*} \mathrm{DIST}^{*} \mathrm{LAB} \Rightarrow$ EXP.

The first solution path suggests that the combination of a zero tariff, being closely located to the EU, weak institutions and few labour rights violations are sufficient for a high relative importance of the EU as an export market for pineapples. This combination of conditions is found in Benin, Côte d'Ivoire and Togo. The second solution path suggests that the combination of a zero tariff, enabling institutions, distance far from the EU, and many labour rights violations also suffice for having a high relative importance of the EU market in the case of Colombia and Panama. Whenever one of these two combinations of conditions is present, the EU market for pineapple exports is relatively important. Moreover, the outcome is not attributable to a unique factor or individual condition. Results suggest that the quality of institutions is less relevant in the West African exporters of pineapples compared to the Latin American exporters such as Colombia and Panama. The reverse is true for the protection of labour rights, which matters more for the West African exporters than for Colombia and Panama.

Regarding the model fit, the solution has a consistency value of 0.857 , a score that indicates that some cases deviate from the conditional patterns. The solution coverage is $51 \%$ of the cases, meaning that half of the cases are not explained by the solution, which limits the generalisability of the results. The raw and unique coverage values are rather low for both paths. The first path is covered by more cases and is of more empirical importance than the second path.

In sum, the model confirms that a combination of conditions (protection of labour rights, institutional quality, tariff regime and distance) explain the relative share of pineapple exports to the EU market. Surprisingly, the solutions did not cover as many cases of pineapple exporting countries as we had expected. This result is probably influenced by the outcome definition, because West African producers heavily rely on the EU market for pineapple exports, receiving a score 1 on the outcome variable. These countries have few alternative market channels except for local consumption. The market outlets for Costa Rican pineapples are ample. Half of the Costa Rican pineapples go to the US market. Defined in the way it is, the outcome variable underestimates the importance of the EU for Costa Rican pineapples, which are market leaders in terms of volume exported to the EU.

\section{Conclusion}

The protection of labour standards is increasingly relevant for trade relations because of consumers' ethical concerns and corresponding attention paid by firms and policy makers. The European market is an important destination for agricultural export commodities and European firms might favour countries with good labour standards to establish their global value chains in addition to decisions based on cost logic. However, our understanding of the extent to which labour standards play a decisive role in exporting to the EU is limited. The advantage of QCA is that it allows the combination of conditions that lead to the outcome to be determined. In our study, the results distinguished between two distinct paths, contrasting African to Latin American cases. On the one hand, the combinations of few labour violations and weak institutions are sufficient in the case of Benin, Côte d'Ivoire and Togo. On the other hand, the combinations of many labour violations and enabling institutions are sufficient in the case of Panama and Colombia.

Our QCA analysis, based on countries that export pineapples to the EU, shows that protection of labour standards matters in a number of cases. However, it does not always play a role, and it is never a sufficient condition on its own for determining exports to the European market. Rather, we have shown that (1) having a zero tariff is necessary for a large share of export to the EU, and (2) labour standards protection can make a difference when the institutional quality is weak.

The first finding highlights the relevance of preferential market access. Having zero tariff market access constitutes a necessary (but not sufficient) condition for a relatively large export share to the EU. Interestingly, distance to the European market in itself does not appear as a sufficient condition as it needs to be complemented with other factors such as labour standards protection and institutions. The second finding does indeed sug-

Table 4. Conservative solution of sufficient conditions.

\begin{tabular}{lllll}
\hline Solution paths & $\begin{array}{l}\text { Inclusion Sufficiency } \\
\text { Score }\end{array}$ & Raw Coverage & Unique Coverage & Cases \\
\hline 1) TAR $^{*} \sim \mathrm{INST}^{*} \sim \mathrm{DIST}^{*} \sim \mathrm{LAB}$ & 0.856 & 0.302 & 0.302 & Benin, Côte d'Ivoire, Togo \\
2) TAR*INST*DIST*LAB & 0.857 & 0.208 & 0.208 & Colombia, Panama \\
\hline Total Solution & 0.857 & 0.510 & & \\
\hline
\end{tabular}

Notes: TAR: zero tariff; LAB: many labour violations; DIST: far from EU; INST: enabling institutions.

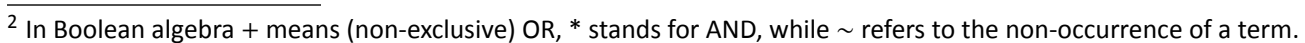


gest that labour standards protection can matter but only in combination with the quality of institutions. Specifically, countries where labour standards are respected have been relatively successful exporters to the EU market even if the institutional context is weak (e.g. in Benin, Côte d'Ivoire, Togo), whereas countries where labour standards are violated will only have a large share of exports when their limited compliance with labour rights is compensated for with a high institutional quality (e.g. Panama, Colombia). Countries that do not manage to compensate for their weak track record of labour rights with a higher institutional quality (e.g. Honduras and Guatemala) will not benefit from a larger relative export share to the EU.

Further research needs to engage in a more profound analysis of the interaction between the importance of institutional quality for determining export performance, which has been well established in research on international trade, and compliance with labour rights conventions. The finding that weak institutional quality in the African cases did not hinder business probably reflects the political and economic relations which, historically, have facilitated trade with the ACP countries. In addition, the firm and retailer levels should be examined more closely to determine how important compliance with labour standards is in purchasing decisions and how labour standards are monitored in global value chains. Why and how exporters that respect labour standards have managed to export successfully to the EU market despite weak institutions (in African cases) remains to be investigated more closely. Finally, it is unclear to what extent the findings can be generalised beyond the peculiarities of pineapple to other agricultural commodities and value chains such as garments.

We can conclude that even (Latin American) violators of labour standards have a relatively large export share to the EU, provided that they benefit from zero tariffs and have good institutions. This calls into question whether the image of the EU market as being very demanding in terms of labour standards coincides with the purchasing behaviour of importers, retailers and consumers, who might not sufficiently reward or incentivise compliance with labour standards at sourcing sites. Although the EU is explicit in its discourse on promoting labour standards, it appears to miss its intended leverage effect on actual export decisions and consequently fails to drive higher standards in sourcing sites.

\section{Acknowledgments}

The authors would like to thank Bruno Vandecasteele, Lore Van den Putte and the two anonymous reviewers for their insightful comments and suggestions. The article also benefited from the participants' comments in the GIFTA workshop on "Social and Labour Impacts of Free Trade Agreements" (Brussels, 7-8 July 2016), the workshop on "EU Contributions to Sustainable Development" (Leicester, 20 April 2016), the U4 Cluster Con- ference Social Sciences, Economics and Law (Groningen, 4-6 November 2015) and the ECPR summer school in Methods and Techniques (Ljubljana, July 2015). This research was supported by Ghent University's Special Research Fund (BOF).

\section{Conflict of Interests}

The authors declare no conflict of interests.

\section{References}

Anderson, J., \& Marcouiller, D. (2002). Insecurity and the pattern of trade: An empirical investigation. The Review of Economics and Statistics, 84(2), 342-352.

Anker, R., Chernyshev, I., Egger, P., Mehran, F., \& Ritter, J. A. (2003). Measuring decent work with statistical indicators. International Labour Review, 142(2), 146-177.

Babarinde, O., \& Faber, G. (2007). Exports by leastdeveloped countries in Sub-Saharan Africa: The role of preferential systems, geography and institutions. In G. Faber \& J. Orbie (Eds.), European Union trade politics and development everything but arms unravelled (pp. 96-116). London: Routledge.

Barrientos, S., \& Smith, S. (2007). Do workers benefit from ethical trade? Assessing codes of labour practice in global production systems. Third World Quarterly, 28(4), 713-729.

Centre for the Promotion of Imports from Developing Countries. (2015). Promising EU export markets for fresh pineapples. Centre for the Promotion of Imports from developing countries. Retrieved from https:// www.cbi.eu/sites/default/files/study/tailored-studypineapples-west-africa-europe-promising-eu-markets -fresh-fruit-vegetables-2014.pdf

COMEXT. (2015). International trade dataset: EU Trade Since 1988 by HS2, 4, 6 and CN8 (DS-045409). Eurostat. Retrieved from http://epp.eurostat.ec.europa. eu/newxtweb

Compa, L. (2003). Assessing assessments: A survey of efforts to measure countries' compliance with freedom of association standards. Comparative Labor Law and Policy Journal, 24, 283-320.

Cuyvers, L., \& Van Den Bulcke, D. (2007). The quantification of respect for selected core labour standards: Towards a social development index? In D. Kucera (Ed.), Qualitative indicators of labour standards: Comparative methods and applications (pp. 115-144). Dordrecht: Springer.

De Groot, H. L. F., Linders, G., Rietveld, P., \& Subramanian, U. (2004). The institutional determinants of bilateral trade patterns. Kyklos, 57(1), 103-124.

Distelhorst, G., \& Locke, R. M. (2017). Does compliance pay? Firm-level trade and social institutions. (Watson Institute for International and Public Affairs Research Paper No. 2017-37). Retrieved from https://ssrn.com/abstract=2885455 
Donaghey, J., Reinecke, J., Niforou, C., \& Lawson, B. (2014). From employment relations to consumption relations: Balancing labor governance in global supply chains. Human Resource Management, 53(2), 229-252.

Emlinger, C., Jacquet, F., \& Chevassus Lozza, E. (2008). Tariffs and other trade costs: Assessing obstacles to Mediterranean countries' access to EU-15 fruit and vegetable markets. European Review of Agricultural Economics, 35(4), 409-438.

Eurobarometer. (2016). The European year for development-Citizen's views on development, cooperation and aid. Special Eurobarometer 411. Retrieved from https://ec.europa.eu/europeaid/ sites/devco/files/sp441-devco-report-final_en.pdf

European Commission. (2015a). Monitoring agri-trade policy-2. Distribution of EU agri-food imports by import regimes in 2014. Retrieved from http:// ec.europa.eu/agriculture/trade-analysis/map/20152_en.pdf

European Commission. (2015b). Trade for all: Towards a more responsible trade and investment policy. Retrieved from http://trade.ec.europa.eu/doclib/docs/ 2015/october/tradoc_153846.pdf

European Commission. (2016). TARIC Consultation database. European Commission. Retrieved from http://ec.europa.eu/taxation_customs/dds2/taric/ta ric_consultation.jsp?Lang=en

European Commission. (2017). Report on the implementation of the trade policy strategy Trade for All. Delivering a progressive trade policy to harness globalisation (COM(2017)491 final). Brussels: European Commission.

European Parliament. (2017). Resolution of 12 September 2017 on the impact of international trade and the EU's trade policies on global value chains (2016/2301(INI)). Brussels: European Commission.

Fair Trade Advocacy Office. (2015a). Decent work, fair supply chains, sustainable development. Make fruit fair. Retrieved from http://www.makefruitfair.org

Fair Trade Advocacy Office. (2015b). An innovative EU approach in support of Fair Trade practices in the new EU Trade \& Investment Strategy (Fair Trade Advocacy Position paper, v. 18 July 2015). Retrieved from http://www.fairtrade-advocacy.org/images/EU _trade_strategy_and_promotion_of_Fair_Trade_prac tices-July2015.pdf

Fair Trade International. (2016). Annual report 20152016: Power in partnership. Fair Trade International. Retrieved from https://annualreport15-16. fairtrade.net/en/power-in-partnership

Giumelli, F., \& Van Roozendaal, G. (2016). Trade agreements and labour standards clauses: Explaining labour standards developments through a qualitative comparative analysis of US free trade agreements. Global Social Policy, 17(1), 38-61.

Greenhill, B., Mosley, L., \& Prakash, A. (2009). Tradebased diffusion of labor rights: A panel study, 1986-
2002. Political Science Review, 103(4), 669-690.

Grofman, B., \& Schneider, C. Q. (2009). An introduction to crisp set QCA, with a comparison to binary Logistic regression. Political Research Quarterly, 62(4), 662-672.

Hefeker, C., \& Wunner, N. (2002). The producer interest in foreign labor standards. European Journal of Political Economy, 18(3), 429-447.

Hurst, P. (2005). Agricultural workers and their contribution to sustainable agriculture and rural development. Rome: FAO-ILO-IUF.

International Labour Organization. (2016). Assessment of labour provisions in trade and investment arrangements (Studies on Growth with Equity Series). Geneva: ILO.

Jansen, M., \& Nordås, H. K. (2004). Institutions, trade policy and trade flows (WTO Staff Working Paper ERSD2004-02). Retrieved from http://hdl.handle.net/ $10419 / 90666$

Katz, A., Vom Hau, M., \& Mahoney, J. (2005). Explaining the great reversal in Spanish America fuzzy-set analysis versus regression analysis. Sociological Methods \& Research, 33(4), 539-573.

Kaufmann, D., Kraay, A., \& Mastruzzi, M. (2010). The worldwide governance indicators: Methodology and analytical issues (World Bank Policy Research Working Paper No. 5430). Retrieved from http://papers. ssrn.com/sol3/papers.cfm?abstract_id $=1682130$

Knudsen, J. S., \& Moon, J. (in press). Visible hands: National government and international corporate social responsibility. Cambridge: Cambridge University Press.

Kolben, K. (2017). A supply chain approach to trade and labor provisions. Politics and Governance, 5(4), 60-68.

Kucera, D. (2001). The effects of core worker rights on labour costs and foreign direct investment: Evaluating the conventional wisdom (IILS Discussion Paper 130/2001). Geneva: International Institute for Labour Studies.

Kucera, D., \& Sari, D. (2016). New labour rights indicator: Method and results, version September 2015 (Centre for Global Workers' Rights, Working Paper Series, Working Paper 002). Retrieved from http://Iser.la. psu.edu/gwr/documents/KuceraandSariMethodsand Results2012.pdf

Kucera, D., \& Sarna, R. (2006). Trade union rights, democracy, and exports: A gravity model approach. Review of International Economics, 14(5), 859-882.

Levchenko, A. (2007). Institutional quality and international trade. The Review of Economic Studies, 74(3), 791-819.

Marx, A., Rihoux, B., \& Ragin, C. (2014). The origins, development, and application of Qualitative Comparative Analysis: The first 25 years. European Political Science Review, 6(1), 115-142.

Mayer, T., \& Zignago, S. (2011). Notes on CEPII's distances measures: The GeoDist Database (CEPII 
Working paper 2011-25). Retrieved from http:// www.cepii.fr/CEPII/en/publications/wp/abstract.asp ?NoDoc $=3877$

Méon, P. G., \& Sekkat, K. (2008). Institutional quality and trade: Which institutions? Which trade? Economic Inquiry, 46(2), 227-240.

Mosley, L. (2008). Workers' rights in open economies. Global production and domestic institutions in the developing world. Comparative Political Studies, 41(4/5), 674-714.

Mosley, L. (2017). Workers' rights in global value chains: Possibilities for protection and for peril. New Political Economy, 22(2), 153-168.

Mosley, L., \& Uno, S. (2007). Racing to the bottom or climbing to the top? Economic globalization and collective labor rights. Comparative Political Studies, 40(8), 923-948.

Neumayer, E., \& de Soysa, I. (2006). Globalization and the right to free association and collective bargaining: An empirical analysis. World Development, 34(1), 31-49.

O'Rourke, D. (2003). Outsourcing regulation: Analyzing nongovernmental systems of labor standards and monitoring. The Policy Studies Journal, 31(1), 1-29.

Orbie, J., \& Martens, D. (2016). EU trade policy and developing countries: Towards a more ethical agenda? In P. Garcia-Duran \& M. Millet (Eds.), Different glances at EU trade policy (pp. 73-82). Barcelona: CIBOD.

Pajunen, K. (2008). Institutions and inflows of Foreign Direct Investment: A fuzzy-set analysis. Journal of International Business Studies, 39(4), 652-669.

Ragin, C. (2006). Set relations in social research: Evaluating their consistency and coverage. Political Analysis, 14, 291-310.

Reinecke, J., \& Donaghey, J. (2015). After Rana Plaza: Building coalitional power for labour rights between unions and (consumption-based) social movement organisations. Organization, 22(5), 720-740.

Richards, D. L., Gelleny, R. D., \& Sacko, D. H. (2001). Money with a mean streak? Foreign economic penetration and government respect for human rights in developing countries. International Studies Quarterly, 45(2), 219-239.

Rodrik, D. (1996). Labor standards in international trade: Do they matter and what do we do about them? In R. Lawrence, D. Rodrik, \& J. Whalley (Eds.), Emerging agenda for global trade: High stakes for developing countries (pp. 35-80). Washington, DC: Overseas Development Council.

Schneider, C. Q., \& Wagemann, C. (2012). Set-theoretic methods for the social sciences: A guide to qualitative comparative analysis. Cambridge: Cambridge University Press.

Stolle, D., \& Micheletti, M. (2013). Political consumerism: Global responsibility in action. Cambridge: Cambridge University Press.

Teitelbaum, E. (2010). Measuring trade union rights through violations recorded in textual sources: An assessment. Political Research Quarterly, 63(2), 461-474.

Thiem, A., Baumgartner, M., \& Bol, D. (2016). Still lost in translation! A correction of three misunderstandings between configurational comparativists and regressional analysts. Comparative Political Studies, 49(6), 742-774.

Toffel, M., Short, J., \& Ouellet, M. (2015). Code in context: How states, markets, and civil society shape adherence to global labor standards. Regulation \& Governance, 9(3), 205-223.

United Nations COMTRADE. (2015). International trade statistics. UN COMTRADE Database. Retrieved from http://comtrade.un.org

Vagneron, I., Faure, G., \& Loeillet, D. (2009). Is there a pilot in the chain? Identifying the key drivers of change in the fresh pineapple sector. Journal of Food Policy, 34(5), 437-446.

Van den Putte, L., \& Orbie, J. (2015). EU bilateral trade agreements and the surprising rise of labour provisions. The International Journal of Comparative Labour Law and Industrial Relations, 31(3), 263-284.

Velluti, S. (2015). The EU's social dimension and its external trade relations. In A. Marx, J. Wouters, G. Rayp, \& L. Beke (Eds.), Global governance of labour rights: Assessing the effectiveness of transnational public and private policy initiatives (pp. 42-62). Cheltenham: Edward Elgar.

Vis, B. (2012). The comparative advantages of fsQCA and regression analysis for moderately large- $\mathrm{N}$ analyses. Sociological Methods \& Research, 41(1), 168-198.

Vogt, J. (2017). The Bangladesh Sustainability Compact: An effective tool for promoting workers' rights? Politics and Governance, 5(4), 80-92.

\section{About the Authors}

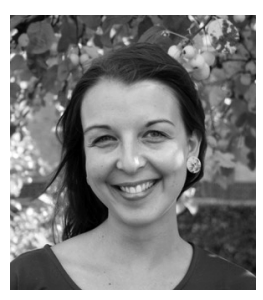

Annelien Gansemans is a PhD candidate in the Department of Agricultural Economics at Ghent University. She is involved in an interdisciplinary research project focusing on the implications of EU trade for plantation workers' livelihoods in Central America. She has a special research interest in corporate social responsibility and labour rights in agricultural value chains. 


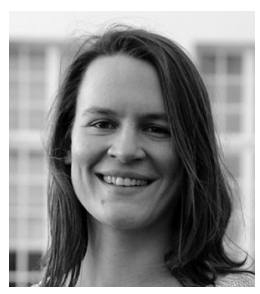

Deborah Martens has been a PhD candidate at the Centre for EU Studies (CEUS) since December 2014. She works on an interdisciplinary research project with Annelien Gansemans from Ghent University's Department of Agricultural Economics, focusing on the impact of EU trade on social development in Latin America. Together, their aim is to understand how labour conditions in the agricultural sector are influenced by trading with the EU. Their research explores the macro level (EU politics), meso level (EU firms' corporate social responsibility) and micro level (pineapple plantations in Central America).

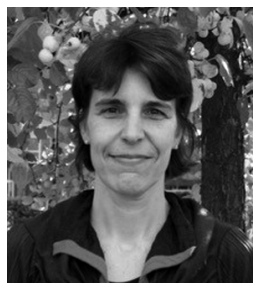

Marijke D'Haese is a Professor of Rural Development Economics at Ghent University. In 2003, she obtained a PhD on the economics of woolgrowers' associations in the Transkei region in South Africa. She is involved in several projects on diverse aspects of agricultural development in the South. She previously worked as an Assistant Professor in the Development Economics Group at Wageningen University and has conducted fieldwork in Ethiopia, Bolivia, South Africa and Costa Rica.

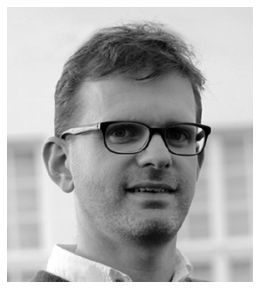

Jan Orbie is the Director of the Centre for EU Studies (CEUS) and a Professor in the Department of Political Science at Ghent University. His primary research focus is on the EU's foreign policy and specifically the "soft" dimensions (trade, development, social, democracy promotion) of EU external relations. In particular, he follows the interaction between trade, development and foreign policies from an EU perspective. He teaches similar subjects within Ghent University's Master's programme in EU Studies. 
Annex

Table A1. Raw and calibrated data of the outcome and conditions.

\begin{tabular}{|c|c|c|c|c|c|c|c|c|c|c|c|}
\hline & \multirow[b]{2}{*}{ Case } & \multicolumn{2}{|c|}{ EXP } & \multicolumn{2}{|c|}{ INST } & \multicolumn{2}{|c|}{ LAB } & \multicolumn{2}{|c|}{ TAR } & \multicolumn{2}{|c|}{ DIST } \\
\hline & & Cal. & Raw & Raw & Cal. & Raw & Cal. & Raw & Cal. & Raw & Cal. \\
\hline 1 & Cameroon & 1 & 0.98 & -1.04 & 0 & 5.61 & 0.56 & 0 & 1 & 5272 & 0.255 \\
\hline 2 & Côte d'Ivoire & 1 & 0.98 & -1.12 & 0 & 2.40 & 0.24 & 0 & 1 & 5126 & 0.216 \\
\hline 3 & Benin & 1 & 0.93 & -0.64 & 0 & 2.38 & 0.24 & 0 & 1 & 4948 & 0.180 \\
\hline 4 & Mauritius & 1 & 0.92 & 0.95 & 1 & 3.67 & 0.37 & 0 & 1 & 9453 & 0.927 \\
\hline 5 & Togo & 1 & 0.86 & -0.94 & 0 & 1.31 & 0.13 & 0 & 1 & 4979 & 0.182 \\
\hline 6 & Ghana & 1 & 0.82 & -0.04 & 1 & 2.02 & 0.2 & 0 & 1 & 5058 & 0.200 \\
\hline 7 & Panama & 0.67 & 0.67 & -0.23 & 1 & 6.67 & 0.67 & 0 & 1 & 8814 & 0.888 \\
\hline 8 & Dominican Republic & 0.67 & 0.62 & -0.7 & 0 & 3.81 & 0.38 & 0 & 1 & 7325 & 0.726 \\
\hline 9 & Thailand & 0.67 & 0.52 & -0.17 & 1 & 6.09 & 0.61 & 2.3 & 0 & 9261 & 0.917 \\
\hline 10 & Costa Rica & 0.67 & 0.48 & 0.47 & 1 & 2.9 & 0.29 & 0 & 1 & 9046 & 0.904 \\
\hline 11 & Ecuador & 0.67 & 0.40 & -1.16 & 0 & 4.17 & 0.42 & 0 & 1 & 9535 & 0.931 \\
\hline 12 & Colombia & 0.67 & 0.38 & -0.39 & 1 & 5.27 & 0.53 & 0 & 1 & 8874 & 0.892 \\
\hline 13 & South Africa & 0.33 & 0.28 & -0.11 & 1 & 1.68 & 0.17 & 0 & 1 & 9536 & 0.931 \\
\hline 14 & Honduras & 0.33 & 0.10 & -1.17 & 0 & 4.50 & 0.45 & 0 & 1 & 8916 & 0.895 \\
\hline 15 & Tanzania & 0 & 0.02 & -0.56 & 0 & 4.22 & 0.42 & 0 & 1 & 7242 & 0.714 \\
\hline 16 & Bolivia & 0 & 0 & -1.04 & 0 & 3.28 & 0.33 & 0 & 1 & 10261 & 0.958 \\
\hline 17 & Brazil & 0 & 0 & -0.11 & 1 & 4.07 & 0.41 & 2.3 & 0 & 9666 & 0.937 \\
\hline 18 & China & 0 & 0 & -0.49 & 1 & 10 & 1 & 2.3 & 0 & 7971 & 0.810 \\
\hline 19 & Guatemala & 0 & 0 & -1.1 & 0 & 7.08 & 0.71 & 0 & 1 & 9095 & 0.907 \\
\hline 20 & India & 0 & 0 & -0.1 & 1 & 6.83 & 0.68 & 2.3 & 0 & 6420 & 0.577 \\
\hline 21 & Malaysia & 0 & 0 & 0.51 & 1 & 6.65 & 0.67 & 2.3 & 0 & 10261 & 0.958 \\
\hline 22 & Mexico & 0 & 0 & -0.56 & 0 & 4.15 & 0.42 & 0 & 1 & 9259 & 0.917 \\
\hline 23 & Paraguay & 0 & 0 & -0.87 & 0 & 3.45 & 0.35 & 0 & 1 & 10417 & 0.963 \\
\hline 24 & Philippines & 0 & 0 & -0.55 & 0 & 5.81 & 0.58 & 2.3 & 0 & 10516 & 0.965 \\
\hline 25 & Uganda & 0 & 0 & -0.36 & 1 & 3.70 & 0.37 & 0 & 1 & 6219 & 0.540 \\
\hline 26 & USA & 0 & 0 & 1.6 & 1 & 4.57 & 0.46 & 5.8 & 0 & 5892 & 0.460 \\
\hline
\end{tabular}

Notes: EXP: high importance EU; INST: enabling institutions; LAB: many labour violations; TAR: zero tariff; DIST: far from EU. 